\title{
Quaternary climatic control of biogenic magnetite production and eolian dust input in cores from the Mediterranean Sea
}

\author{
Jaume Dinarès-Turell ${ }^{a, *}$, Babette A.A. Hoogakker ${ }^{b}$, Andrew P. Roberts ${ }^{b}$, \\ Eelco J. Rohling ${ }^{\mathrm{b}}$, Leonardo Sagnotti ${ }^{\mathrm{a}}$ \\ a Istituto Nazionale di Geofisica e Vulcanologia (INGV), Via di Vigna Murata 605, 00143 Rome, Italy \\ b School of Ocean and Earth Science, University of Southampton, Southampton Oceanography Centre, European Way, \\ Southampton SO14 $3 \mathrm{ZH}$, UK
}

Received 25 March 2002; received in revised form 5 June 2002; accepted 18 October 2002

\begin{abstract}
We report high-resolution magnetic measurements from two Mediterranean piston cores: LC07 (Sicily Strait) and LC10 (Ionian Sea). Magnetostratigraphic results and $\delta^{18} \mathrm{O}$ data provide age constraints for core LC07, where we investigate magnetic property variations for two age intervals (0-600 kyr and 660-1020 kyr). For core LC10, rock magnetic parameters appear to be climatically controlled and are used to derive an astronomically tuned age model for the interval between 780 and $1200 \mathrm{kyr}$. In core LC07, the dominant control on the magnetic properties appears to be glacial-interglacial variations in the concentration of biogenic magnetite. In addition, an increased contribution from high coercivity minerals (e.g. hematite and/or goethite) probably reflects an enhanced eolian input during glacial periods. Climatic control of magnetotactic bacterial populations has been previously suggested in other environments, but this is the first such report from the Mediterranean. In contrast, the rock magnetic response to Quaternary climatic variability in core LC10 seems to be better expressed by variations in the concentration of high coercivity magnetic minerals. The contrast between a dominantly detrital/eolian flux and a dominantly biogenic flux at the same time for the two Mediterranean settings might relate to the presence of an active current regime in the Sicily Strait, which might decrease delivery of an eolian component to the seafloor compared to the deep Ionian Sea.
\end{abstract}

(c) 2002 Elsevier Science B.V. All rights reserved.

Keywords: environmental magnetism; biogenic magnetite; eolian dust; glacial-interglacial cycles; Mediterranean Sea

\section{Introduction}

It is generally accepted that changes in the long-term quasi-periodic variations in the Earth's orbit (eccentricity, obliquity and precession) have

\footnotetext{
* Corresponding author. Fax: +39-06-51860397.

E-mail address: dinares@ingv.it (J. Dinarès-Turell).
}

driven global climatic changes. The astronomical forcing of climate (or Milankovitch theory) suggests that the seasonal and latitudinal distribution of insolation (solar radiation) is the driving force in global climate and that the Quaternary waxing and waning of northern continental ice sheets was regulated by insolation variations as a consequence of changes in the Earth's orbit (Berger, 1988). Oxygen isotope variations measured from 
foraminifera shells in deep-sea cores represent a proxy for changes (largely) in global ice volume and hence of sea-level, although oxygen isotopes also reflect temperature and large-scale salinity variations. The chronology of oxygen isotopic records is tied to the geomagnetic polarity time scale and fine-tuned using astronomical tuning from Milankovitch theory (Shackleton et al., 1990).

Circulation in the Mediterranean Sea is anti-estuarine, where the surface waters enter from the Atlantic and leave the Mediterranean at depth. The general circulation has a thermohaline origin due to an excess of evaporation over precipitation and riverine input and is controlled by the ex- change of water through the Strait of Gibraltar. Import of nutrient-depleted Atlantic surface waters and the export of nutrients in saline deep waters cause the eastern Mediterranean basin to be a nutrient desert with low primary production in the surface waters. Hemipelagic sediments in the eastern Mediterranean contain numerous organic-rich layers or sapropels. Two main mechanisms are invoked to explain the origin of sapropels, including climate-induced productivity (e.g. Calvert, 1983) and preservation due to depletion of oxygen in the bottom waters (e.g. RossignolStrick et al., 1982). Sapropels formed during humid climatic conditions at times of maximum Northern Hemisphere insolation. In the western

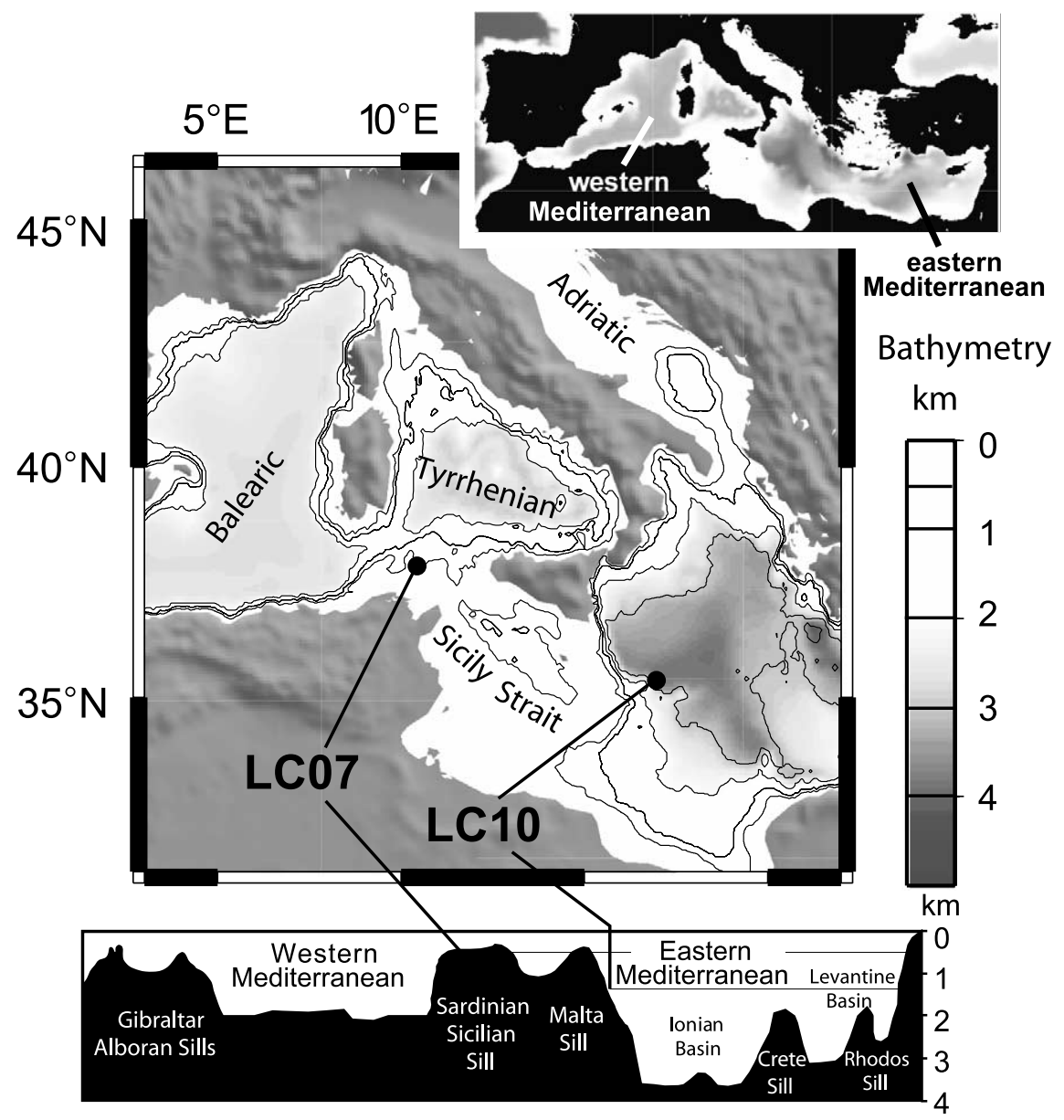

Fig. 1. Map of the Mediterranean Sea with location and setting of cores LC07 and LC10 in the Tyrrhenian Sea and the Ionian Sea, respectively. 
Mediterranean basin, due to its shallower depth (Fig. 1) and inflowing of Atlantic waters, the occurrence of sapropels is more restricted.

In this study, we describe rock magnetic variations along two Mediterranean piston cores that appear to correlate with indices of climatic change. The location of these two cores, with contrasting lithology, at differrent settings on either side of the Strait of Sicily (see below), enables evaluation of the response of sedimentary processes and assessment of the link to climatic forcing.

\section{Materials and methods}

Mediterranean piston cores LC07 $\left(38^{\circ} 08.72^{\prime} \mathrm{N}\right.$, $10^{\circ} 04.73^{\prime} \mathrm{E}$; length $23.66 \mathrm{~m}$, water depth $488 \mathrm{~m}$ ) and $\mathrm{LC} 10\left(35^{\circ} 12.77^{\prime} \mathrm{N}, 16^{\circ} 34.88^{\prime} \mathrm{E}\right.$; length 19.86 $\mathrm{m}$, water depth $1322 \mathrm{~m}$ ) were collected by the R/V Marion Dufresne in 1995 (MAST II PALAEOFLUX Program) from a location north of the Skerki Channel at the western side of the Sicily Strait (LC07), and on a bank north of Heron Valley at the eastern side of the Sicily Strait (LC10) (Fig. 1). Both cores were continuously sampled with ca. 1-m-long u-channel samples (Tauxe et al., 1983) at the BOSCOR repository at the Southampton Oceanography Centre. The sediment in core LC07 is a visually homogeneous grey to olive grey foraminifer-rich mud and nannofossil ooze that includes an interval of foraminifer-rich sand from 15.66 to $16.08 \mathrm{~m}$ below sea floor (mbsf). The interval from 15.41 to 15.66 mbsf was not recovered and presumably consisted of sand. The upper $0.5 \mathrm{~m}$ of the core was unsuitable for u-channel sampling due to sediment disturbance. Core LC10 is composed of greyish yellow to olive grey foraminifer-rich mud and nannofossil ooze. Core LC10 also contains dark sapropel layers at different depths and a conspicuous thin tephra layer at about $4.55 \mathrm{mbsf}$ (see below).

Magnetic measurements were made on the uchannels at $1-\mathrm{cm}$ intervals using a 2-G Enterprises high-resolution cryogenic magnetometer with RF SQUID sensors (the half-width of the response function $=4.5 \mathrm{~cm}$ ) in the magnetically shielded room of the INGV. The following components are configured in-line with the magnetometer for u-channel measurements: a Bartington Instruments MS2-C loop sensor (45 mm internal diameter), for measurements of the low-field magnetic susceptibility ( $\kappa)$; an alternating field (AF) demagnetising unit (with three orthogonal AF coils, acting in sequence along the $z, x$ and $y$ axes, respectively), with the optional capability for application of a constant DC field along the $z$ axis to impart an anhysteretic remanence magnetisation (ARM); and a pulse magnetiser, with a maximum field of $0.9 \mathrm{~T}$, for an imparting isothermal remanent magnetisation (IRM) along the axis of the u-channel.

After stepwise demagnetisation of the natural remanent magnetisation of each u-channel, an ARM was imparted (in a peak AF of $100 \mathrm{mT}$ and a superimposed DC bias field of $0.1 \mathrm{mT}$ ) that was then stepwise AF demagnetised in eight steps up to $100 \mathrm{mT}$. After demagnetisation of the ARM, an IRM was produced by applying a 0.9-T pulsed field along the $z$ axis. The IRM was then AF demagnetised in five steps up to $60 \mathrm{mT}$. Finally, a new IRM was produced again in a forward field of $0.9 \mathrm{~T}$, followed by a back-field IRM at $0.3 \mathrm{~T}$. The IRM measurements were used to calculate the 'hard' IRM (HIRM), which is defined as $\left(\mathrm{IRM}_{0.3 \mathrm{~T}}+\mathrm{IRM}_{0.9 \mathrm{~T}}\right) / 2$, and the S-ratio, which is defined as $-\mathrm{IRM}_{-0.3 \mathrm{~T}} / \mathrm{IRM}_{0.9 \mathrm{~T}}$ (Stober and Thompson, 1979). All remanence measurements have been corrected to compensate for the slightly different response function widths of the transverse ( $x$ and $y$ ) and axial (z) SQUID sensors. Susceptibility measurements from the MS2-C sensor loop were calibrated to SI units by application of a constant conversion factor, experimentally determined on the INGV system.

Hysteresis loops were measured for small dried sediment chips collected at $5-\mathrm{cm}$ intervals between 0.58 and $5.68 \mathrm{mbsf}$ and between 17.43 and 23.38 mbsf in addition to samples distributed in the intermediate part of the core (224 samples in total). Hysteresis measurements were made using a Micromag alternating gradient magnetometer (AGM, Princeton Measurements Corporation) at the University of Utrecht, The Netherlands. Values of saturation magnetisation $\left(\mathrm{M}_{\mathrm{s}}\right)$, saturation remanence $\left(\mathrm{M}_{\mathrm{rs}}\right)$ and coercive force $\left(\mathrm{H}_{\mathrm{c}}\right)$ were de- 
termined from hysteresis loops. The coercivity of remanence $\left(\mathrm{H}_{\mathrm{cr}}\right)$ was also obtained from backfield demagnetisation of $\mathrm{M}_{\mathrm{rs}}$ using the AGM.

Magnetic extracts were examined using a scanning electron microscope (SEM) and a transmission electron microscope (TEM). Extracts where obtained by dissolving the sediment in distilled water and then dispersing the sediment with ultrasonic treatment. Then, a rare-earth magnet was placed in the suspended slurry for a few seconds and the magnetic particles were removed with distilled water. This procedure was repeated a few times. This simple method proved to be efficient for the studied sediments from core LC07, where 1-2 $\mathrm{g}$ of sediment was enough to obtain magnetic extracts suitable for electron microscope analysis.

The planktonic foraminifer Neogloboquadrina pachyderma (right-coiling or dextral variety) was selected for oxygen and carbon isotope analysis. Core LC07 was sampled at 5-cm intervals, except for the sandy interval between 15.4 and 16.08 mbsf. Fifteen to twenty specimens of $N$. pachyder$m a$ were picked from the $250-400-\mu \mathrm{m}$ size fraction for measurements. $N$. pachyderma occurs almost continuously throughout core LC07 and continuous stable isotope signals were obtained. Prior to isotopic analysis, specimens were cleaned with methanol and dried overnight in an oven at $70^{\circ} \mathrm{C}$. Oxygen and carbon isotope ratios were measured in a stable isotope ratio mass spectrometer (Europa GEO 20 20), with individual acid bath carbonate preparation lines. Analytical precision of powdered carbonate standards is $\pm 0.06 \%$ for $\delta^{18} \mathrm{O}$ and $\delta^{13} \mathrm{C}$. Isotope data for core LC07 are

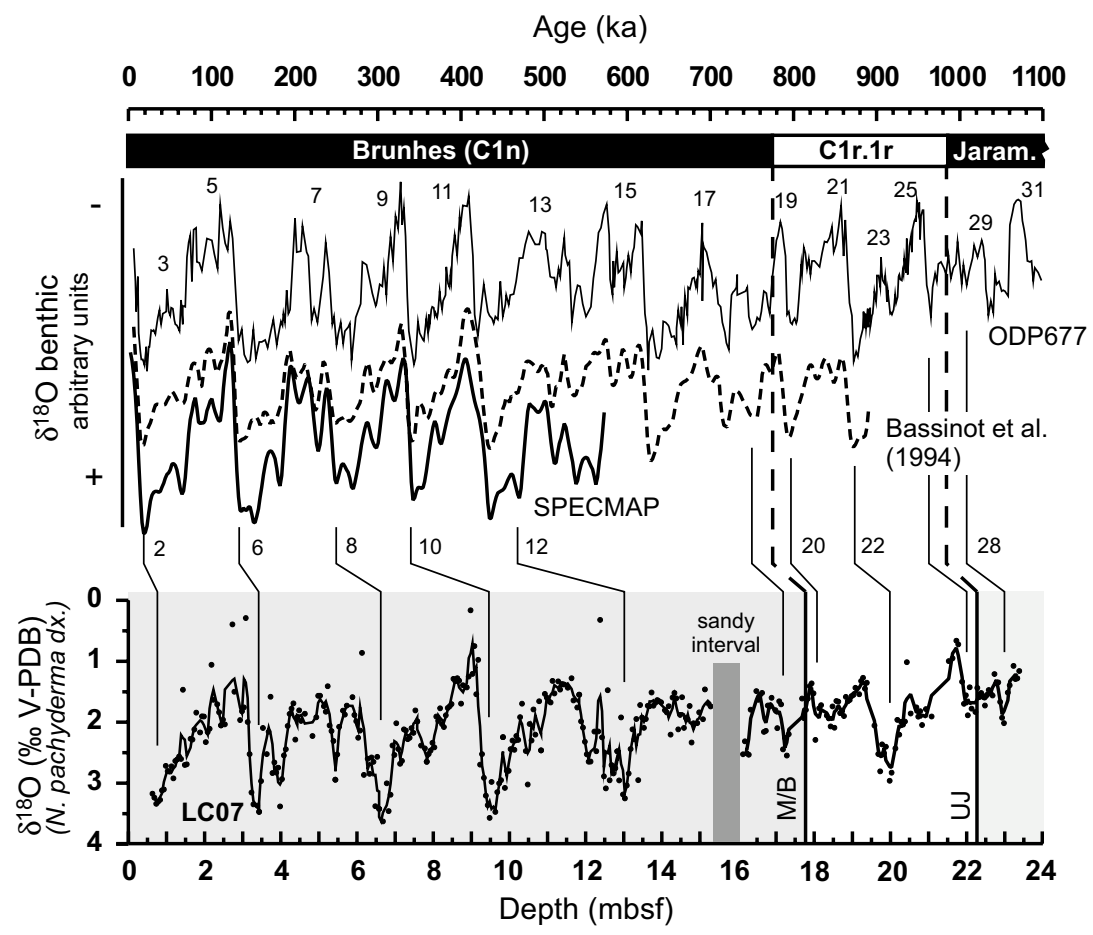

Fig. 2. $\delta^{18} \mathrm{O}$ for Mediterranean core LC07 from Neogloboquadrina pachyderma (dextral) plotted vs. depth (a line following the three-point running mean is drawn through the data). The occurrence of a foraminifer-rich sandy interval from 15.66 to 16.08 mbsf, and the position of the Matuyama/Brunhes (M/B, $17.83 \mathrm{mbsf}$ ) and upper Jaramillo (UJ, 22.45 mbsf) reversal boundaries are indicated. Standard benthic $\delta^{18} \mathrm{O}$ curves, such as SPECMAP (Imbrie et al., 1984), the stack of Bassinot et al. (1994), and the ODP Site 677 record (Shackleton et al., 1990) are plotted on their corresponding age models together with the Geomagnetic Polarity Time Scale of Cande and Kent (1995). The main $\delta^{18} \mathrm{O}$ stages are numbered and correlation lines are drawn between the standard curves and data from core LC07 (see Table 1 for a complete set of correlation points). 
Table 1

Depth position of oxygen isotope stages/events in core LC07 and their respective ages

\begin{tabular}{|c|c|c|}
\hline Oxygen isotope stage/event & $\begin{array}{l}\text { Depth } \\
\text { (mbsf) }\end{array}$ & $\begin{array}{l}\mathrm{Age}^{\mathrm{a}} \\
(\mathrm{ka})\end{array}$ \\
\hline 2.2 & 0.73 & 20 \\
\hline 3.1 & 1.10 & 28 \\
\hline 3.3 & 1.43 & 53 \\
\hline 4.2 & 1.53 & 64 \\
\hline 5.1 & 2.18 & 80 \\
\hline 5.2 & 2.43 & 86 \\
\hline 5.3 & 2.73 & 100 \\
\hline 5.4 & 2.93 & 108 \\
\hline 5.5 & 3.10 & 122 \\
\hline 6.3 & 3.73 & 146 \\
\hline 6.4 & 3.93 & 155 \\
\hline 7.3 & 5.23 & 214 \\
\hline 7.4 & 5.43 & 228 \\
\hline 7.5 & 6.13 & 237 \\
\hline 8.2 & 6.18 & 249 \\
\hline 8.3 & 6.33 & 257 \\
\hline 8.4 & 6.63 & 269 \\
\hline 8.5 & 7.55 & 287 \\
\hline 8.6 & 7.83 & 299 \\
\hline 9.1 & 8.53 & 310 \\
\hline 9.2 & 8.73 & 320 \\
\hline 9.3 & 8.93 & 328 \\
\hline 10.2 & 9.58 & 340 \\
\hline 11.1 & 10.33 & 368 \\
\hline 11.2 & 10.48 & 375 \\
\hline 12.1 & 12.38 & 426 \\
\hline 12.2 & 12.53 & 431 \\
\hline 12.3 & 12.3 & 451 \\
\hline 12.4 & 13.03 & 471 \\
\hline 15.1 & 15.13 & 572 \\
\hline 17 & 16.48 & 695 \\
\hline 18 & 17.28 & 755 \\
\hline 19 & 17.93 & 783 \\
\hline 20 & 18.43 & 798 \\
\hline 21 & 19.28 & 860 \\
\hline 22 & 19.98 & 874 \\
\hline 23 & 20.43 & 903 \\
\hline 25 & 21.73 & 951 \\
\hline 26 & 22.23 & 964 \\
\hline 27 & 22.40 & 990 \\
\hline 28 & 22.98 & 1006 \\
\hline
\end{tabular}

a Ages are derived from Imbrie et al. (1984) down to oxygen isotope event 15.1 and from Chen et al. (1995), Shackleton et al. (1990) and Bassinot et al. (1994) for older stages.

expressed in per mil (\%o) relative to the Vienna Pee Dee Belemnite standard (V-PDB). A total of 388 samples were analysed. The derived $\delta^{18} \mathrm{O}$ curve was initially divided into the standard $\delta^{18} \mathrm{O}$ stages following the nomenclature of Emilia- ni (1955) and Shackleton and Opdyke (1973), where even numbered stages represent glacial intervals with heavier oxygen isotopic values, and odd numbered stages represent interglacial intervals. The oxygen isotope stages (OIS) were then further subdivided into substages or events based on Imbrie et al. (1984) and Prell et al. (1986).

\section{Construction of the age models}

\subsection{Core $\mathrm{LCO7}$}

Fourteen alternating glacial and interglacial stages were recognised in core LC07. The stages can be clearly correlated with the SPECMAP curve (Imbrie et al., 1984) and that of Williams et al. (1988) between glacial OIS 2 to possibly interglacial OIS 29 (Fig. 2; Table 1). Ages for the $\delta^{18} \mathrm{O}$ stages and events (Table 1) are derived from Imbrie et al. (1984) until $\delta^{18} \mathrm{O}$ event 15.1 and from Shackleton et al. (1990), Bassinot et al. (1994) and Chen et al. (1995) for older stages. The Matuyama/Brunhes (M/B) boundary at 17.8

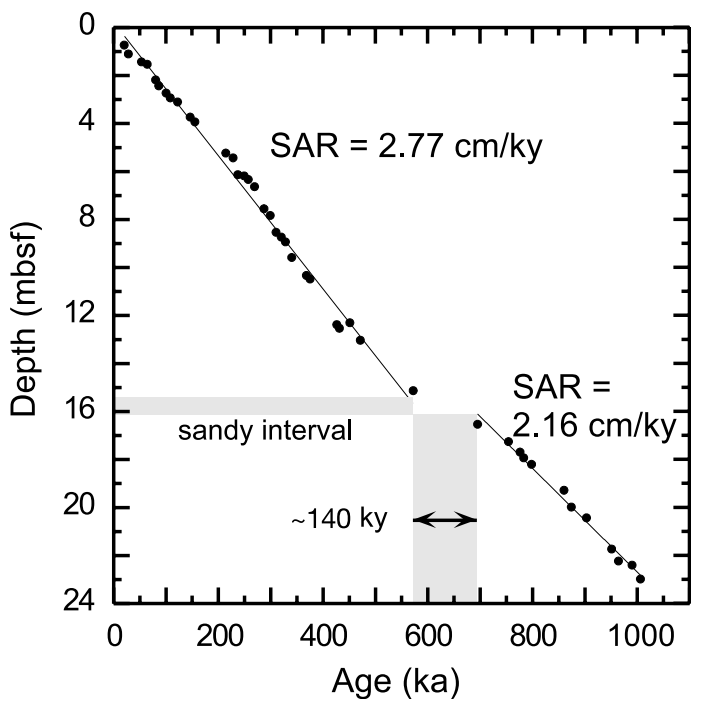

Fig. 3. Age control points used to derive a detailed age model for core LC07 (see Table 1 for details). Linear fits for these points above and below the sandy interval imply a condensed section with a maximum duration of $140 \mathrm{kyr}$. These linear fits also indicate mean sediment accumulation rates (SAR) of 2.77 and $2.16 \mathrm{~cm} / \mathrm{kyr}$ for the upper and lower segments of the core, respectively. 
mbsf and the Upper Jaramillo (UJ) reversal at 22.4 mbsf coincide with OIS 19 and OIS 27, respectively (Table 1). The astronomically calibrated ages of $0.778 \mathrm{Ma}(\mathrm{M} / \mathrm{B})$ and $0.990 \mathrm{Ma}$ (UJ) are assigned to these reversal boundaries (Shackleton et al., 1990; Tauxe et al., 1996). The new $\delta^{18} \mathrm{O}$ data confirm the age model derived previously for the lower part of core LC07 (754 $1033 \mathrm{ka}$ ) by Dinarès-Turell et al. (2002), who correlated and tuned rock magnetic parameters to a standard $\delta^{18} \mathrm{O}$ curve and astronomical solution. Here, we divide the core $\mathrm{LC} 07$ record into two parts for converting depth into age, because of the occurrence of the sand interval between 15.4 and $16.08 \mathrm{mbsf}$. The results of two linear interpolations (Fig. 3) indicate that our age model yields nearly linear sedimentation rates for the two portions of the core. The sand interval is interpreted to represent a winnowed lag deposit, and, according to our age model, appears to represent a condensed section spanning part of OIS 15 and 16, and accounts for a maximum time interval of $\sim 140 \mathrm{kyr}$ (or $\sim 63 \mathrm{kyr}$ in the more accurate age model derived below). Using the calibration points listed in Table 1, in addition to the dated magnetostratigraphic boundaries, a precise age model was derived for the entire core by linear interpolation between these tie points using the AnalySeries software (Paillard et al., 1996). This procedure assumes constant sedimentation rates between tie points. The age models derived from OIS 2 down to OIS 15 (Fig. 4a) and from OIS 17

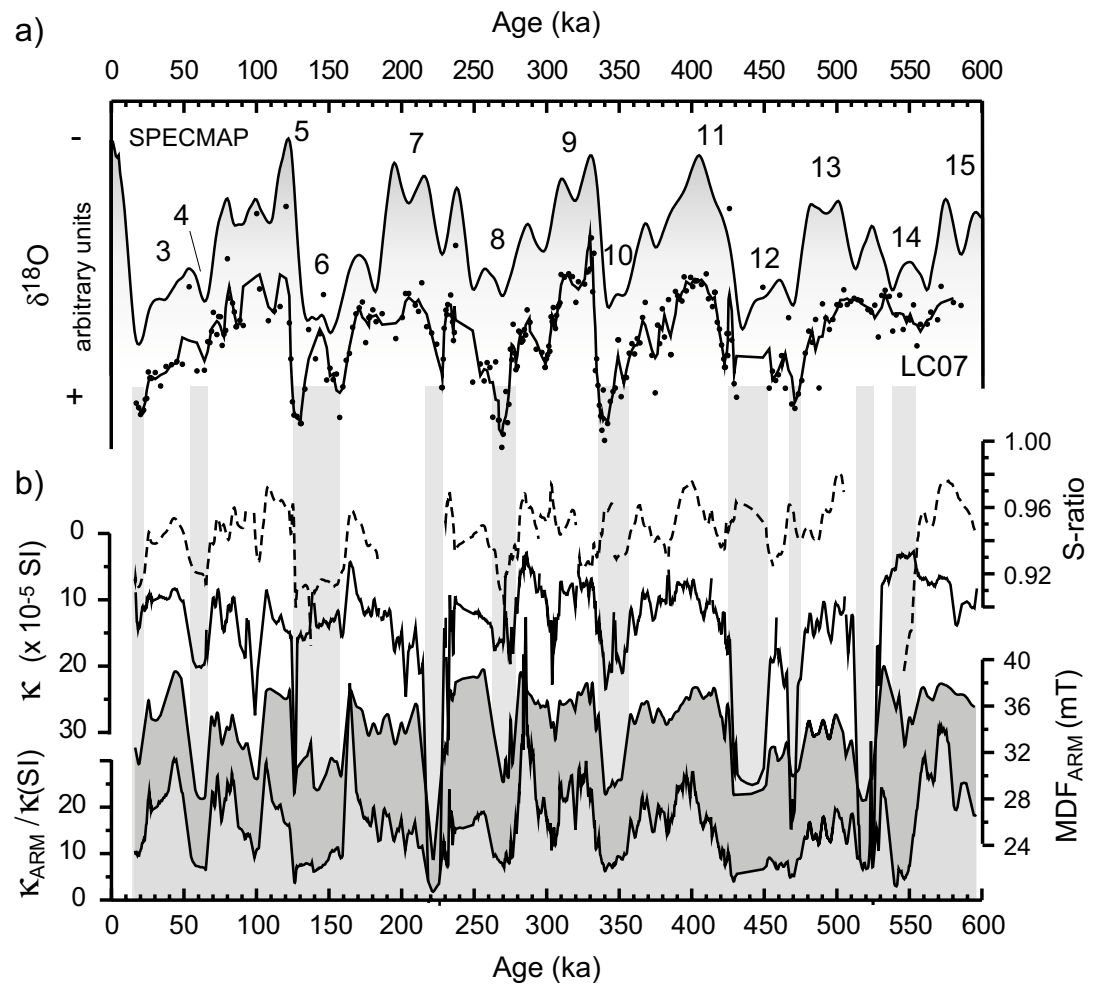

Fig. 4. (a) Benthic $\delta^{18} \mathrm{O}$ SPECMAP stack (Imbrie et al., 1984) with identification of $\delta^{18} \mathrm{O}$ stages and the $\delta^{18} \mathrm{O}$ record for the upper part of core LC07. The interval shown is from above the sandy interval and is derived from age-depth pointers in Table 1 (see text). (b) Down-core variations of magnetic properties from core LC07: S-ratio; $\kappa$, low-field volume magnetic susceptibility; $\mathrm{MDF}_{\mathrm{ARM}}$, median destructive field of the ARM; and $\kappa_{\mathrm{ARM}} / \kappa$ ratio. Gaps in the S-ratio curve denote intervals where IRM measurements were beyond the maximum range of our magnetometer, as a result of which data are not available. Shaded vertical strips are intervals with characteristic rock magnetic properties that correspond to relatively cold events or interglacial stages (see text for discussion). 

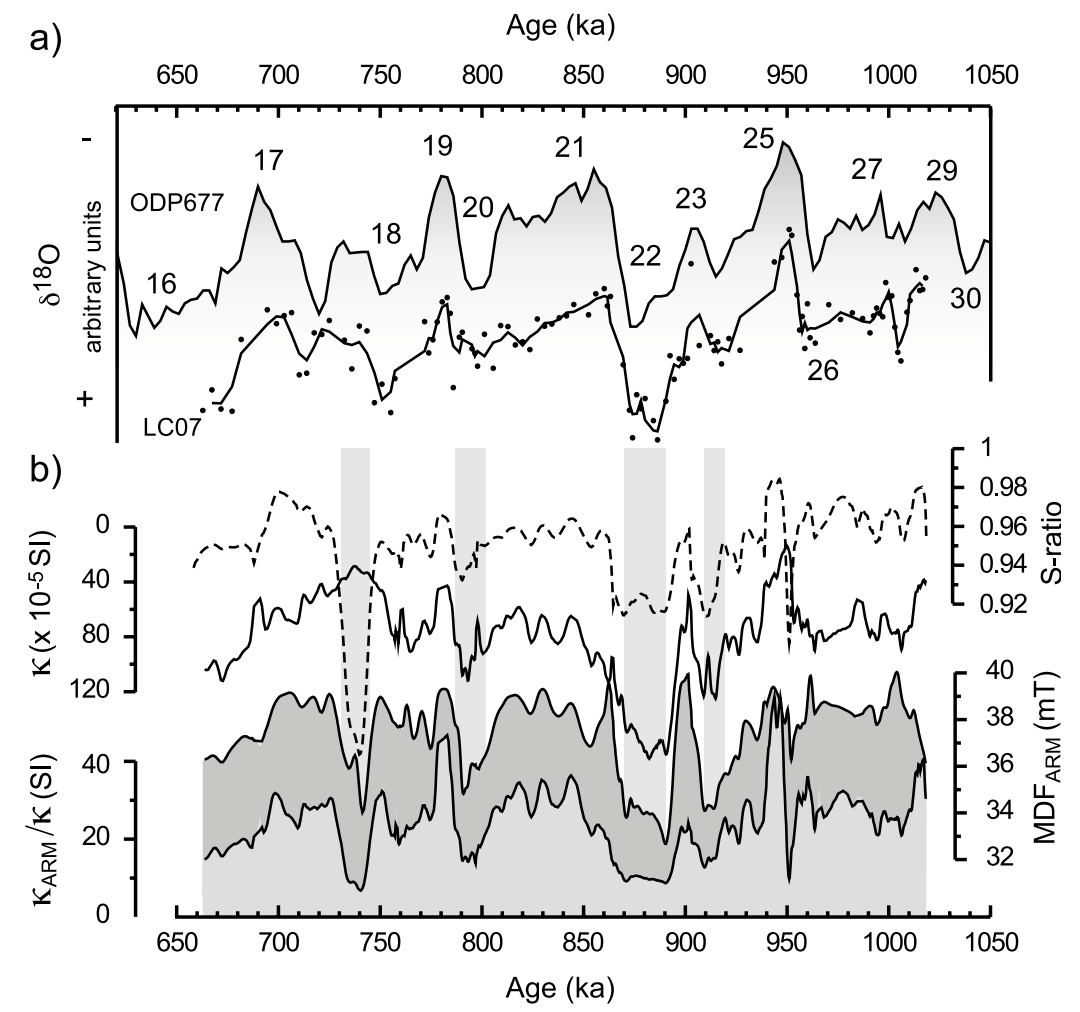

Fig. 5. (a) Benthic $\delta^{18} \mathrm{O}$ record for ODP Site 677 (Shackleton et al., 1990), with identification of $\delta^{18} \mathrm{O}$ stages and the $\delta^{18} \mathrm{O}$ record for the lower part of core LC07 below the sandy interval. (b) Down-core variations of magnetic properties from core LC07: $\mathrm{S}$-ratio; $\kappa, \mathrm{MDF}_{\mathrm{ARM}}$, and $\kappa_{\mathrm{ARM}} / \kappa$ ratio. Shaded vertical strips are intervals with characteristic rock magnetic properties (see text for discussion).

to OIS 29 (Fig. 5a) produce a good match between the $\delta^{18} \mathrm{O}$ data from core $\mathrm{LC} 07$ and the respective target curves.

\subsection{Core $L C 10$}

A $\delta^{18} \mathrm{O}$ stratigraphy, which is the most widely used chronostratigraphic dating tool for marine sediments of the Brunhes Chron, is not available for core LC10. Here, we examine the lower part of the LC10 record where the presence of geomagnetic reversals enables development of an age model. The LC10 record is included here because of the different environmental setting with reference to core LC07. Comparison of the two records, therefore, should permit analysis of the controlling factors on the magnetic properties over the same time interval. As noted above, core $\mathrm{LC} 10$ is located in the Ionian Sea at a greater water depth than core LC07 (Fig. 1), and is lithologically variable with colour banding (from greyish-whitish to yellowish-brownish) and includes two conspicuous dark, organic-rich sapropel layers in the lower interval studied here (Fig. 6). We have derived a tentative magnetostratigraphy from $13.40 \mathrm{mbsf}$ to the bottom of the core (Fig. 7c). Although the NRM inclination after AF demagnetisation at $40 \mathrm{mT}$ is rather noisy, it is possible to suggest a magnetostratigraphic interpretation in which the M/B boundary, the Jaramillo subchron and the Upper Cobb Mountain reversal are identified (Fig. 7c). Astronomically calibrated ages for these reversals (see above) imply sedimentation rates of $1.78 \mathrm{~cm} / \mathrm{kyr}$ and 1.40 $\mathrm{cm} / \mathrm{kyr}$ for the Brunhes and the Matuyama portions, respectively, in core LC10. 


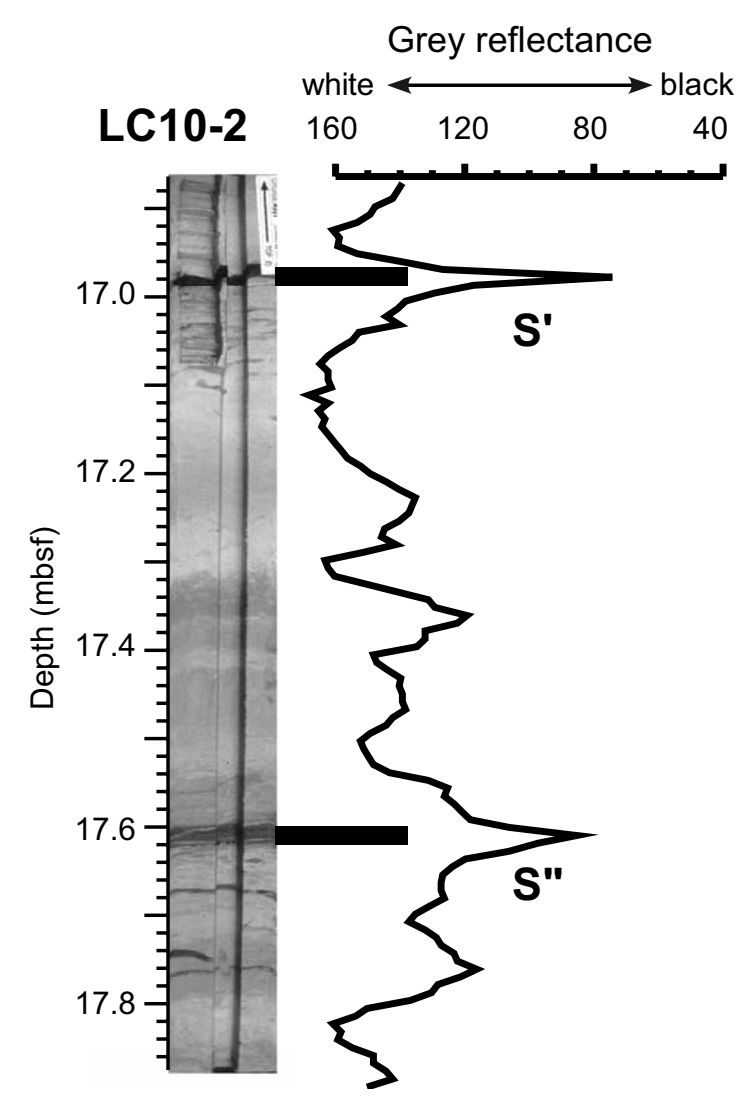

Fig. 6. Photograph of the split core LC10-section 2 (after extraction of the u-channel sample from the middle part). The lithological colour banding is evident, as well as two conspicuous dark sapropel layers labelled $\mathrm{S}^{\prime}$ and $\mathrm{S}^{\prime \prime}$. The grey reflectance data for the same interval clearly reflect the lithological banding.

\section{Rock magnetic results}

\subsection{Core $\mathrm{LCO7}$}

Dinarès-Turell et al. (2002) presented evidence that magnetite is the main magnetic mineral in the LC07 core. Rock magnetic parameters can therefore be used to estimate grain size variation of magnetite particles throughout the core. Plots of ARM susceptibility ( $\left.\kappa_{\text {ARM }}\right)$ against low-field susceptibility (К) (Fig. 8a; Banerjee et al., 1981; King et al., 1983) can be used to make inferences about grain size variations. For magnetite, magnetic susceptibility is largely independent of grain size over the size range from $0.1 \mu \mathrm{m}$ to $6 \mathrm{~mm}$ (Heider et al., 1996), whereas $\kappa_{\mathrm{ARM}}$ has a clear grain size dependence, with peak values within the stable single domain (SD) grain size range (ca. 0.02-0.05 $\mu \mathrm{m}$ ) (Maher, 1988). The $\kappa_{\mathrm{ARM}} / \kappa$ ratio therefore decreases for increasing magnetite grain sizes. The 'King plot' for the LC07 core indicates that magnetite particles show a rather conspicuous variation in the fine grain size field (i.e. $<0.1 \mu \mathrm{m}$ ) and that multidomain magnetites are practically absent in the sediments from this core. Such inferences are confirmed by the plot of $\mathrm{MDF}_{\mathrm{ARM}}$ against $\kappa_{\text {ARM }} /$ SIRM (Fig. $8 b$ ), in which we notice that the LC07 data partly overlap with the range of variation for synthetic sub-micron magnetite (MT series of Maher, 1988), but they also extend beyond the MT range. No data fall in the field typical for relatively coarse grain sizes (i.e. magnetites larger than $1 \mu \mathrm{m}$ ). A possible explanation for the significant spreading of grain size dependent rock magnetic parameters in the sub-micron SD range observed in the $\mathrm{LC} 07$ core samples is that magnetite particles in this sequence have two distinct sources: detrital and biogenic. This hypothesis is corroborated by a histogram of the $\kappa_{\text {ARM }} / \kappa$ values (Fig. $8 d$ ), which shows an appreciable tail of values that plot in the field typical of stable SD magnetite grains of likely bacterial origin according to Oldfield (1994) (i.e. ca. 9\% of the values are $>30$ ).

Further evidence for the presence of two climatically controlled sources of magnetite in core LC07 comes from the hysteresis ratios, which show a tightly defined trend within the pseudosingle domain (PSD) field of Day et al. (1977) (Fig. 9a) from relatively 'fine-grained' values for interglacial periods to relatively 'coarse-grained' values for glacial periods. Although interpretation of data on the widely used Day plot can be complex, it is likely that the observed distribution within the PSD field arises from the mixing of two populations of magnetite from different sources. The grain size data shown in Fig. 8 certainly indicate that PSD grain sizes are unlikely. Numerical and physical bimodal mixing of stable SD grains and PSD or MD grains has shown that such mixtures can be misidentified on the Day plot as unimodal size distributions of intermediate 
a)

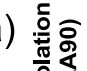

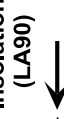

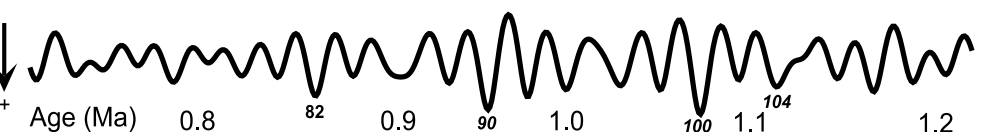

b)

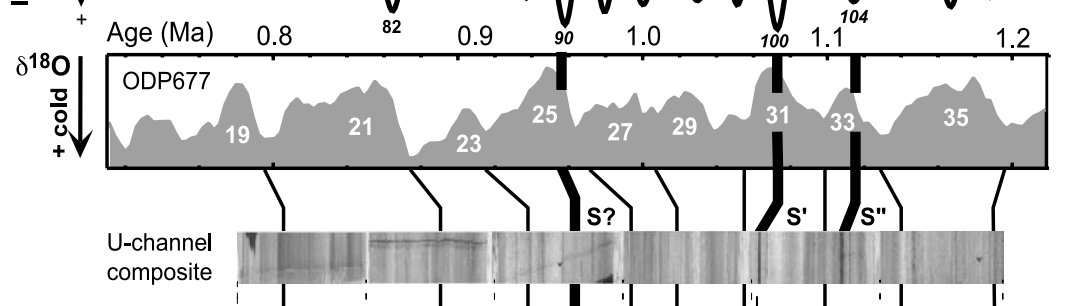

c)
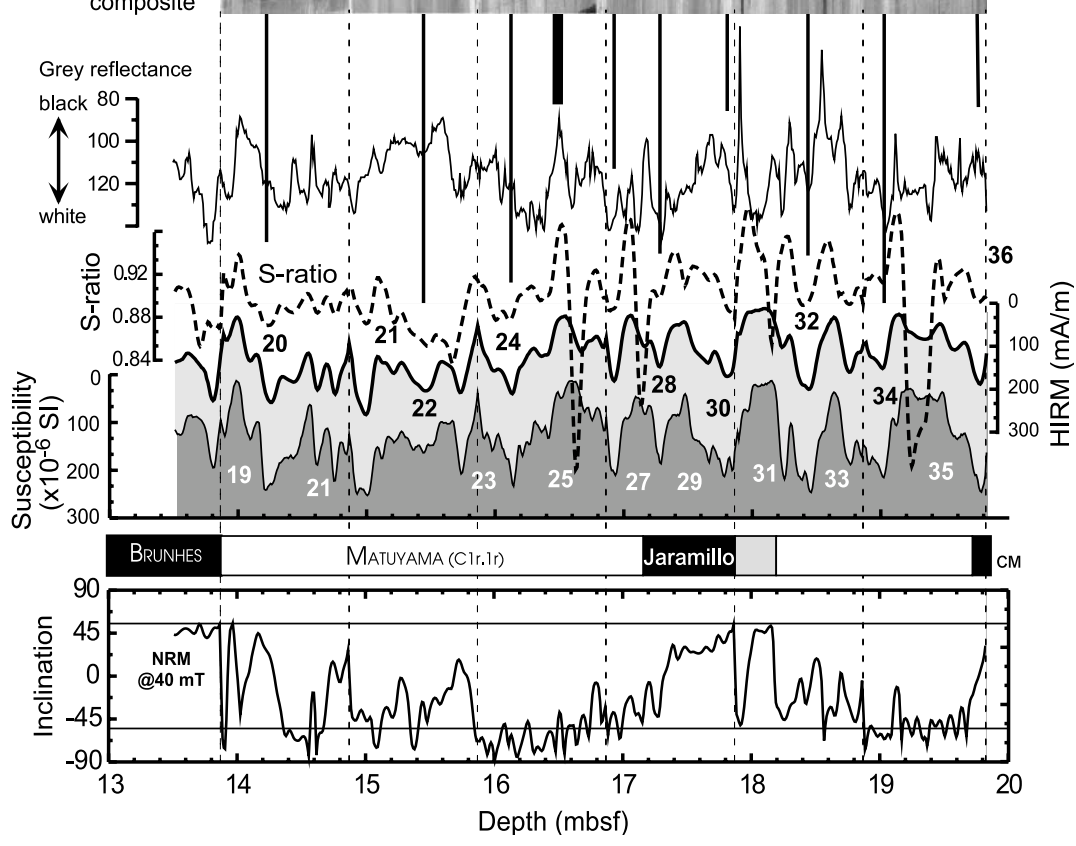

Fig. 7. Correlation of the magnetic properties of the lower part of core LC10 (13.50 to $19.83 \mathrm{mbsf})$ to reference $\delta^{18} \mathrm{O}$ and insolation curves. (a) Astronomically tuned benthic $\delta^{18} \mathrm{O}$ record for ODP Site 677 (Shackleton et al., 1990) with identification of $\delta^{18} \mathrm{O}$ stages; LA90, $65^{\circ} \mathrm{N}$ summer insolation curve of Laskar (1990), where some insolation maxima are numbered. (b) U-channel composite image and down-core variations of grey-reflectance, S-ratio, HIRM and $\kappa$. (c) Magnetostratigraphy for core LC10 derived from inclination data after demagnetisation of the NRM at $40 \mathrm{mT}$. The base of the Brunhes Chron, the Jaramillo Subchron and the Upper Cobb Mountain (CM) reversal are shown. Vertical dashed lines indicate u-channel breaks. Proposed $\delta^{18} \mathrm{O}$ stage identification and correlation lines between rock magnetic data and the reference $\delta^{18} \mathrm{O}$ curve are drawn. Note the occurrence of some dark sapropel layers (labelled $S^{\prime}$ and $S^{\prime \prime}$ ) that correspond to insolation maxima 100 and 104. See text for discussion.

nature, and that simple magnetisation parameters are linearly dependent on the mixing ratio (Roberts et al., 1995; Carter-Stiglitz et al., 2001). There is a direct relationship between $\mathrm{M}_{\mathrm{rs}} / \mathrm{M}_{\mathrm{s}}$ and $\kappa_{\mathrm{ARM}} /$ $\kappa$ ratios, which are both indicative of decreasing grain size at high values (Fig. 9c). The link between the distribution of magnetite grain sizes and the climatic system is also observed in a plot of $\mathrm{M}_{\mathrm{rs}} / \mathrm{M}_{\mathrm{s}}$ against $\delta^{18} \mathrm{O}$ isotope data (Fig. 9b) where coarser grain sizes (i.e. low $\mathrm{M}_{\mathrm{rs}} / \mathrm{M}_{\mathrm{s}}$ ratios) are related to periods of relatively cold climate (i.e. high $\delta^{18} \mathrm{O}$ values).

The presence of a significant biogenic contribution in the LC07 magnetite assemblage is also confirmed by SEM and TEM analyses on magnetic extracts. Representative photographs of the extracts are shown in Fig. 10. Fig. 10a,b provides evidence of bacterial magnetosomes that are highly distinctive because of their regular sizes and shapes (characteristically bullet-shaped mag- 

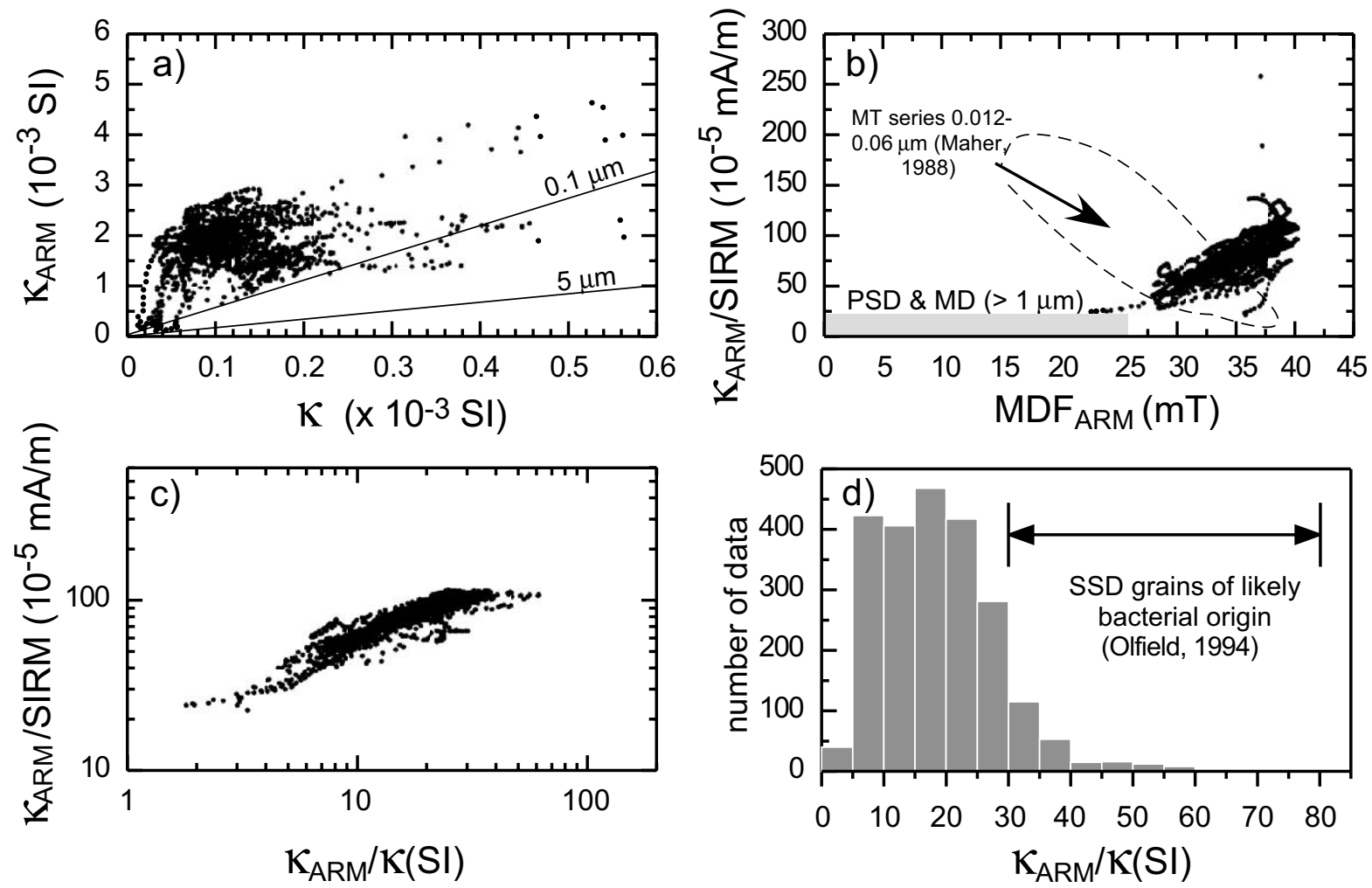

Fig. 8. Plots of grain size dependent rock magnetic parameters for magnetite assemblages in core LC07. (a) 'King plot' of $\kappa_{\text {ARM }}$ against $\kappa$ (Banerjee et al., 1981; King et al., 1983). The linear trends for 0.1 and $5 \mu \mathrm{m}$ grain sizes are shown for reference. (b) Plot of $\kappa_{\mathrm{ARM}} / \mathrm{SIRM}$ against $\mathrm{MDF}_{\mathrm{ARM}}$. The ranges of values typical of synthetic sub-micron magnetites and relatively coarse magnetite particles are indicated by a closed dashed line and a shaded rectangle, respectively (Maher, 1988). (c) Plot of $\kappa_{\mathrm{ARM}} /$ SIRM against $\kappa_{\mathrm{ARM}} / \kappa$, where high values of both parameters indicate a likely bacterial magnetite population (Oldfield, 1994). (d) Histogram of the $\kappa_{\mathrm{ARM}} / \kappa$ values. The range of values typical for stable single domain magnetites of likely bacterial origin (Oldfield, 1994) is also indicated. See text for discussion.

netosomes were also observed). In addition to these magnetic grains of bacterial origin, several larger, less regular magnetic grains are likely to be of detrital origin (Fig. 10c). Energy dispersive $\mathrm{X}$-ray analysis of one of these grains indicates the presence of $\mathrm{Ti}$ and $\mathrm{Fe}$, which suggests that it is a detrital titanomagnetite grain.

\subsection{Core $L C 10$}

In Core LC10, selected rock magnetic parameters can be linked to lithological variations that are expressed by changes in colour and grey-reflectance (Fig. 7). Recognition of magnetic subchrons and the presence of two distinct sapropel layers allows establishment of an age model and correlation of rock magnetic and lithological variations to palaeoclimatic changes, as outlined by the reference oxygen isotopic and $65^{\circ} \mathrm{N}$ astronomical insolation curves. With this correlation, the two sapropels $\left(\mathrm{S}^{\prime}\right.$ and $\left.\mathrm{S}^{\prime \prime}\right)$ correspond to insolation maxima 100 and 104 (other minima in the grey reflectance data could represent 'ghost' sapropels, such as the darker layer at ca. $16.60 \mathrm{mbsf}$, indicated as S? in Fig. 7). For core LC10, the HIRM parameter, which is sensitive to variations in high coercivity minerals such as hematite and goethite, appears to correlate with variations in the $\delta^{18} \mathrm{O}$ reference curve (Fig. 7a,b). In particular, during relatively cold periods there was an increase in the amount of high coercivity minerals of probable eolian origin (i.e. HIRM is high). Conversely, 
a)

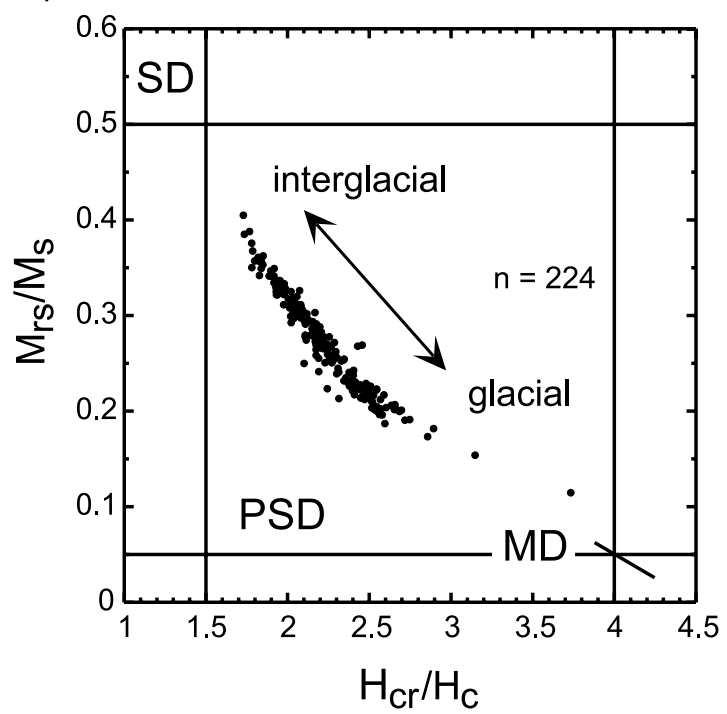

b)

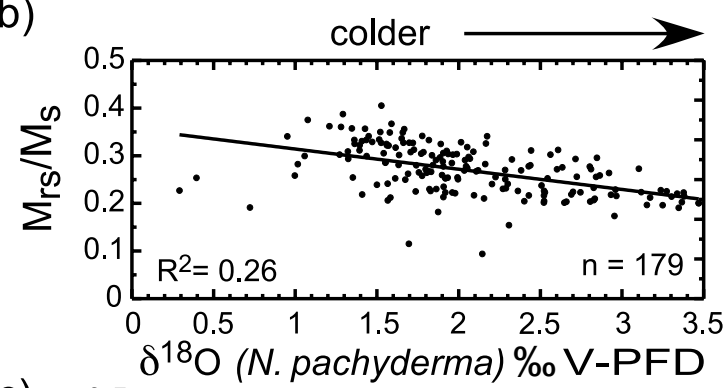

c)

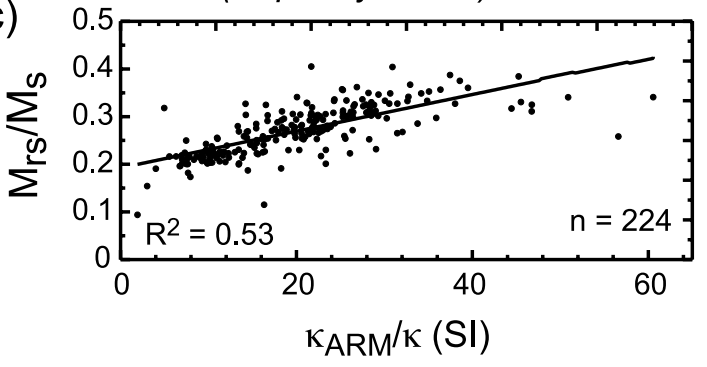

Fig. 9. (a) Plot of $\mathrm{M}_{\mathrm{rs}} / \mathrm{M}_{\mathrm{s}}$ against $\mathrm{H}_{\mathrm{cr}} / \mathrm{H}_{\mathrm{c}}$ with a trend along the pseudo-single domain (PSD) field for glacial and interglacial samples from core LC07. The single domain (SD) and multi domain (MD) fields are also indicated (after Day et al., 1977). (b) Plot of $\mathrm{M}_{\mathrm{rs}} / \mathrm{M}_{\mathrm{s}}$ vs. $\delta^{18} \mathrm{O}$ data for core LC07. There is an inverse linear correlation that indicates larger magnetic grain sizes (low $\mathrm{M}_{\mathrm{rs}} / \mathrm{M}_{\mathrm{s}}$ values) during colder or glacial periods (high $\delta^{18} \mathrm{O}$ values). (c) Plot of $\mathrm{M}_{\mathrm{rs}} / \mathrm{M}_{\mathrm{s}}$ vs. $\kappa_{\mathrm{ARM}} / \kappa$. There is a linear trend, which demonstrates the validity of this parameter as a grain size indicator.

the relative importance of high-coercivity minerals is significantly reduced during intervening warm stages. This interpretation is consistent with several palaeoclimatic reconstructions that point to an increased importance of eolian transport during cold and arid periods, when dust fluxes from continental sources were enhanced (Petit et al., 1981; Robinson, 1986; Peck et al., 1994; Maher and Hounslow, 1999).

The rock magnetic signal in core LC10 is interpreted to be dominated by variations in high coercivity minerals, which show glacial-interglacial cyclicity that suggests variations in flux of eolian particles. This signal contrasts with that in the LC07 core, where fluctuations in concentration of biogenic magnetite seem to represent the dominant control on rock magnetic properties.

\section{The climatic rock magnetic fingerprint in cores LC07 and LC10}

It is well known that in several sedimentary contexts, rock magnetic properties, in particular magnetic susceptibility, can correlate with past climatic and oceanographic changes (e.g. Reynolds and King, 1995; Verosub and Roberts, 1995). The sensitivity of rock magnetic parameters to climatic variations in marine sediments has allowed them to be used to establish age models for cores, where independent dating was not available, by correlating a rock magnetic parameter to an appropriate climatic target curve (i.e. reference oxygen isotopic curve or astronomical solutions; see Robinson, 1986; Guyodo et al., 1999). Variability in the concentration and composition of magnetic material in the marine environment is controlled by changes in sediment source and mode of transport, in addition to diagenetic effects and production of biogenic magnetite (Bloemendal et al., 1992).

Some considerations regarding the connection between rock magnetic parameters and the climatic system can be made for Mediterranean cores LC07 and LC10. Cold glacial events in core LC07 are dominated by the relatively coarser ferrimagnetic fraction (i.e. low $\kappa_{\mathrm{ARM}} / \kappa$ values). Also, a minor change in the overall composition 

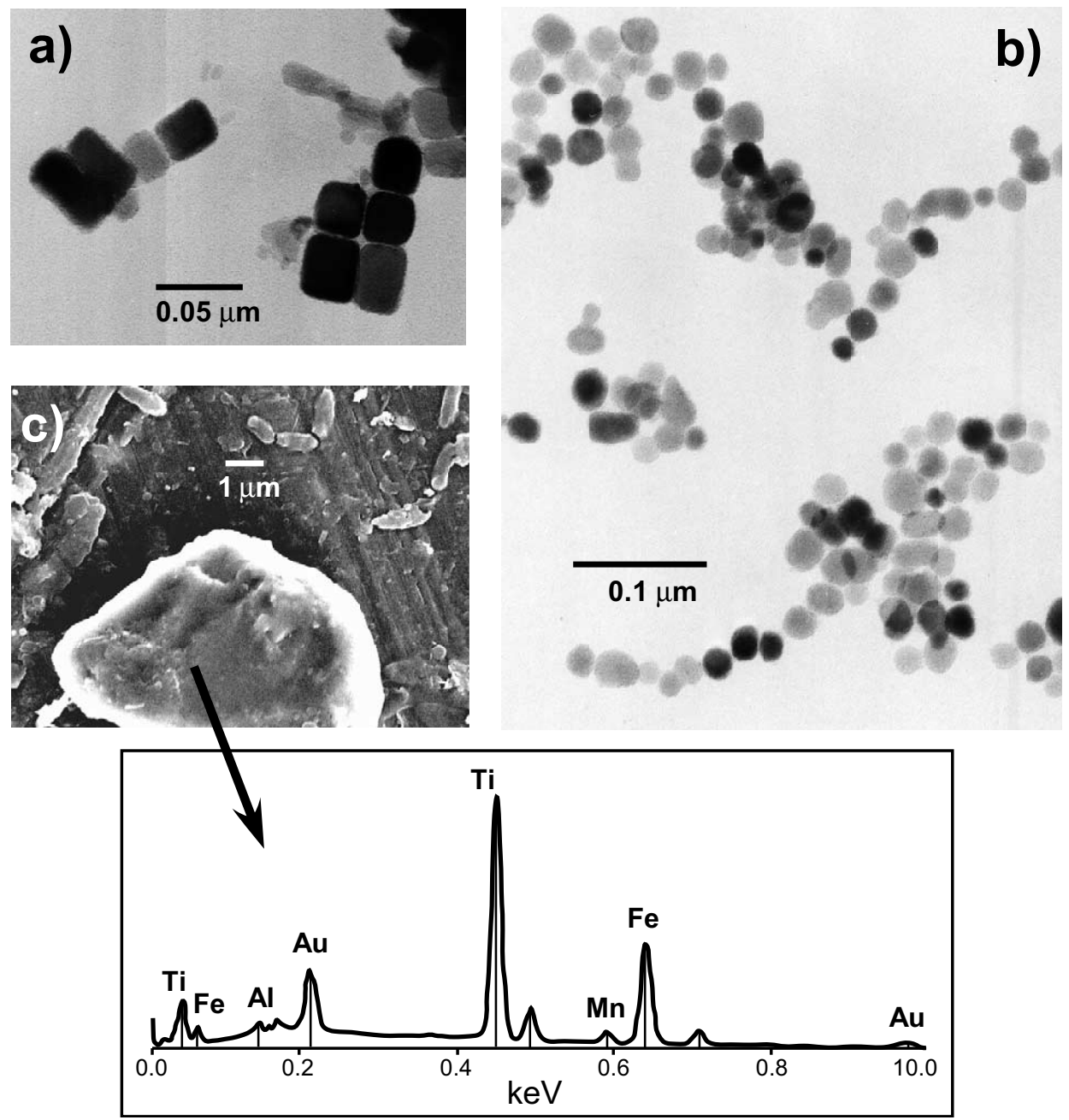

Fig. 10. SEM and TEM photomicrographs of magnetic extracts from core LC07. (a) TEM micrograph of bacterial magnetosome grains (eight-sided parallepipeds or prismatic forms) formed intracellularly by magnetotactic bacteria. (b) TEM micrograph showing bacterial magnetosomes ranging from cuboidal to hexagonal prismatic forms. (c) SEM micrograph of a detrital titanomagnetite grain with corresponding energy dispersive X-ray analysis.

of the mineral magnetic assemblage is generally indicated by relatively lower values of the S-ratio within glacial periods (Fig. 4), which indicates the additional presence of a subordinate percentage of high coercivity minerals during glacial intervals. This suggests an enhanced eolian input during the cold glacial periods. The variation in high coercivity magnetic minerals seems to dominate the rock magnetic signal at the LC10 location, which seems therefore more directly influenced by detrital input, probably from the Saharan region. Dif- ferent responses of rock magnetic properties to glacial-interglacial cycles at the two locations may be due to the difference either in water depth or to their position in different basins. Dust distribution is more likely controlled by wind dynamics, whereas magnetite grain size is more closely dependent on bacterial ecology, in our interpretation of the $\mathrm{LC} 07$ record.

It has been noted by Hesse and Stotlz (1999) that, within sedimentary sequences, intervals of enhanced bacterial magnetite concentration may 
record either conditions favourable to bacterial growth (i.e. a palaeoecological record) and/or conditions favourable to their preservation (i.e. a palaeoredox record). It is difficult to assess which of the two situations is prevalent in the case of core LC07 with the present data set. However, the moderate accumulation rate and moderate water depth with possible weakly oxic or sub-oxic chemistry are more likely to preserve a faithful record of palaeoenvironmental change, in contrast, for example, to deeper cores from the western Mediterranean Sea, which are affected by magnetite dissolution (Channell and Hawthorne, 1990; Torii, 1997).

The climatic forcing of the rock magnetic properties from core LC07 can be further evidenced in a power spectra analysis of some of the rock magnetic parameters. This has been performed after tuning the $\mathrm{LC} 07$ record using the independent age model provided by the $\delta^{18} \mathrm{O}$ isotope data and the magnetostratigraphy as described above. Fig. 11 illustrates the power spectra for the grain size $\kappa_{\mathrm{ARM}} / \kappa$ and $\mathrm{MDF}_{\mathrm{ARM}}$ parameters and corresponding reference $\delta^{18} \mathrm{O}$ data from the SPECMAP stack and ODP Site 677 for the same time slices. Spectral power at the precession and obliquity bands are observed in both the rock magnetic

a) interval 16-596 ka

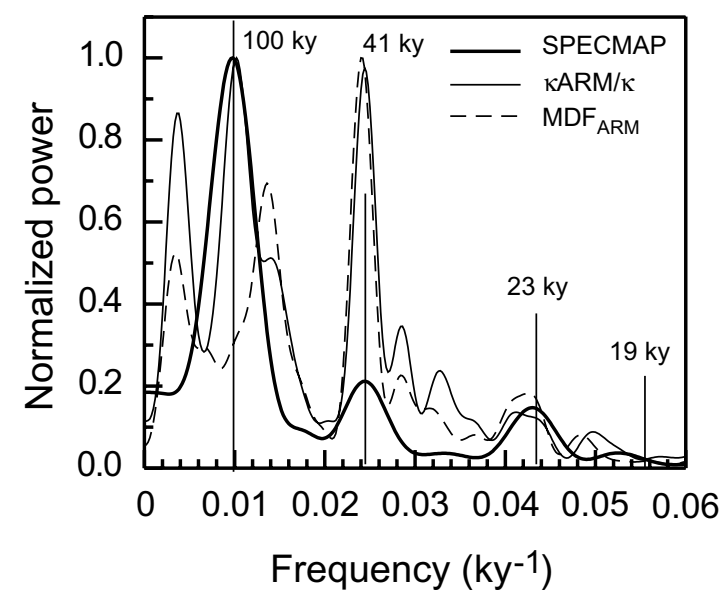

parameters and the $\delta^{18} \mathrm{O}$ data although the relative power is variable (Fig. 11).

\section{Discussion and conclusions}

We have investigated the link between the source of magnetic material and palaeoclimatic changes in two Mediterranean settings. The glacial-interglacial variability in the concentration, mineralogy and grain size of the magnetic assemblage in the studied cores probably results from variations in the source and flux of detrital inputs along with variations in the biogenic flux.

Our results from cores LC07 and LC10 indicate that during cold intervals (stadials), there was an enhanced eolian influx at both studied locations in the form of a larger high coercivity contribution to the magnetic assemblage. This contribution is strongest in the Ionian Sea location. We interpret this eolian flux to represent enhanced African dust input during periods of cold climate. At site LC07, however, palaeoenvironmental changes are better expressed by alternating changes in the average grain size of magnetite particles. The data from core LC07 also suggest a climatic palaeoecological signature. During warm (intersta-

b)

interval 770-1018 ka

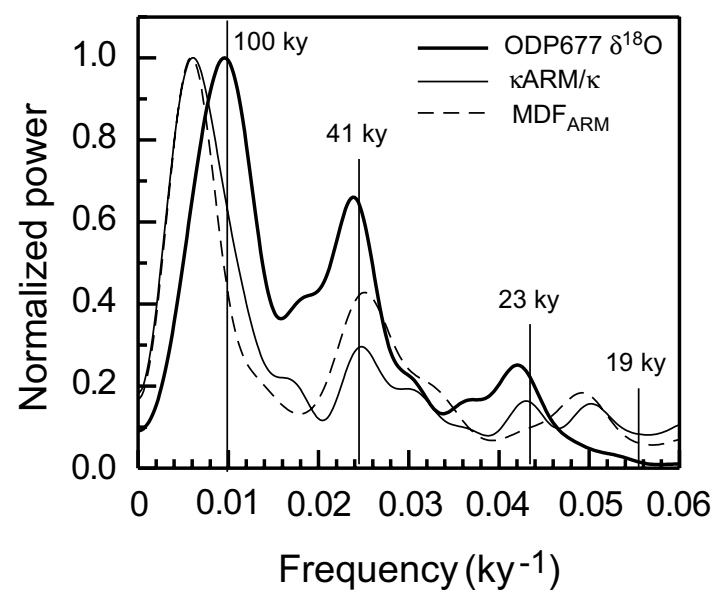

Fig. 11. Normalised power spectra (Blackman-Tukey method with a Bartlett window) of $\delta^{18} \mathrm{O}$ for the SPECMAP stack and ODP Site 677, compared with $\kappa_{\mathrm{ARM}} / \kappa$ and $\mathrm{MDF}_{\mathrm{ARM}}$ from core LC07 for the two considered intervals. The rock magnetic grain size parameters have significant power at the orbital frequencies corresponding to the eccentricity (100 kyr), obliquity (41 kyr) and precession (23 kyr) periods. See text for discussion. 
dial) periods, the growth of a magnetotactic bacterial population was favoured, which enhanced the concentration of fine-grained magnetite within the sediments. The same kind of environmental control on magnetite grain sizes and influence of fossilised bacterial magnetosomes was found in different environments such as the African Atlantic margin (Haag, 2000) and the Chatham Rise, New Zealand (Lean and McCave, 1998). However, the limits of the apparent association between magnetotactic bacteria and climatic forcing remains to be confirmed. Lean and McCave (1998) ruled out enhanced susceptibility during interglacials as an artifact of glacial carbonate dilution or an interglacial increase of terrigenous material.

In conclusion, our data indicate that there is a climatic forcing mechanism controlling the rock magnetic signature in the studied cores. The nature of this forcing is not fully known with the present data set because the terrigenous input can only be quantitatively assessed by means of geochemical and/or petrological analysis. Nevertheless, the overall flux of magnetic material is dominated by Milankovitch-scale fluctuations, as demonstrated by power spectral analysis on rock magnetic data from core LC07 (Fig. 11). Moreover, our observations of enhanced biogenic input during interglacial periods is consistent with the rationale put forward by Hesse (1994), which suggests that environmental conditions and habitat are important factors that affect the morphology of dominant magnetosomes and that reduced oxygenation conditions lead to decreased overall production or preservation of magnetosomes. The difference between the dominant source of the variations in magnetic properties for coeval sediments from the two Mediterranean locations might relate to differences in the hydrography of the two sites. The Sicily Strait has an active current regime, which provides a mechanism for reduced delivery of an eolian component to the seafloor compared to the Ionian Sea (where, for example, S-ratios are much lower (Figs. 5 and 7), as would be expected for this mechanism).

Based on the results presented here, it is clear that magnetic properties can be highly useful for assessing differences in depositional regimes and in analysing climatically driven rock magnetic signals when diagenesis is not the dominant control on magnetic properties. Further work will be needed to assess the nature of the climatic forcing mechanism on these rock magnetic records.

\section{Acknowledgements}

This research was funded by EU Contract ERBFMRXCT98-0247 (MAG-NET) and the EU SOCFAC program. Marianne Hanzlik and Nikolai Petersen are thanked for help with the magnetic extractions and TEM photographs. Richard Pearce helped with the SEM observations at SOC. Martine Paterne provided the shipboard grey reflectance data. Steve Cooke is thanked for assistance with stable isotope analysis. Access to the studied cores was kindly provided by the British Ocean Sediment Core Repository (BOSCOR) at the Southampton Oceanography Centre.

\section{References}

Banerjee, S.K., King, J.W., Marvin, J.A., 1981. A rapid method for magnetic granulometry with applications to environmental studies. Geophys. Res. Lett. 8, 333-336.

Bassinot, F.C., Labeyrie, L.D., Vincent, E., Quidelleur, X., Shackleton, N.J., Lancelot, Y., 1994. The astronomical theory of climate and the age of the Brunhes-Matuyama magnetic reversal. Earth Planet. Sci. Lett. 126, 91-108.

Berger, A., 1988. Milankovitch theory and climate. Rev. Geophys. 26, 624-657.

Bloemendal, J., King, J.W., Hall, F.R., Doh, S.J., 1992. Rock magnetism of late Neogene and Pleistocene deep-sea sediments: relationship to sediment source, diagenetic processes and sediment lithology. J. Geophys. Res. 97, 4361-4375.

Calvert, S.E., 1983. Geochemistry of Pleistocene sapropels and associated sediments from the eastern Mediterranean. Oceanol. Acta 6, 255-267.

Cande, S.C., Kent, D.V., 1995. Revised calibration of the geomagnetic polarity timescale for the Late Cretaceous and Cenozoic. J. Geophys. Res. 100, 6093-6095.

Carter-Stiglitz, B., Moskowitz, B., Jackson, M., 2001. Unmixing magnetic assemblages and the magnetic behavior of bimodal mixtures. J. Geophys. Res. 106, 26397-26411.

Channell, J.E.T., Hawthorne, T., 1990. Progressive dissolution of titanomagnetites at ODP Site 653 (Tyrrhenian Sea). Earth Planet. Sci. Lett. 96, 469-480.

Chen, J., Farrell, J.W., Murray, D.W., Prell, W.L., 1995. Timescale and paleoceanographic implications of a 3.6 m.y. oxygen isotope record from the northeast Indian Ocean 
(Ocean Drilling Program site 758). Paleoceanography 10, $21-47$.

Day, R., Fuller, M., Schmidt, V.A., 1977. Hysteresis properties of titanomagnetites; grain size and compositional dependence. Phys. Earth Planet. Inter. 13, 260-267.

Dinarès-Turell, J., Sagnotti, L., Roberts, A.P., 2002. Relative geomagnetic paleointensity from the Jaramillo subchron to the Matuyama/Brunhes boundary as recorded in a Mediterranean piston core. Earth Planet. Sci. Lett. 194, 327-341.

Emiliani, C., 1955. Pleistocene temperatures. J. Geol. 63, 538578.

Guyodo, Y., Richter, C., Valet, J.P., 1999. Paleointensity record from Pleistocene sediments (1.4-0 Ma) off the California Margin. J. Geophys. Res. 104, 22953-22964.

Haag, M., 2000. Reliability of relative palaeointensities of a sediment core with climatically-triggered strong magnetisation changes. Earth Planet. Sci. Lett. 180, 49-59.

Heider, F., Zitzelsberger, A., Fabian, F., 1996. Magnetic susceptibility and remanent coercive force in grown magnetite crystals from $0.1 \mu \mathrm{m}$ to $6 \mathrm{~mm}$. Phys. Earth Planet. Inter 93, 239-256.

Hesse, P.P., 1994. Evidence for bacterial palaeoecological origin of mineral magnetic cycles in oxic and sub-oxic Tasman Sea sediments. Mar. Geol. 117, 1-17.

Hesse, P., Stotlz, J.F., 1999. Bacterial magnetite and the Quaternary climate record. In: Maher, B.A., Thompson, R. (Eds.), Quaternary Climates, Environments and Magnetism. Cambridge Univ. Press, Cambridge, pp. 163-198.

Imbrie, J., Shackleton, N.J., Pisias, N.G., Morley, J.J., Prell, W.L., Martinson, D.G., Hays, J.D., McIntyre, A., Mix, A.C., 1984. The orbital theory of Pleistocene climate: support from a revised chronology of the marine $\delta^{18} \mathrm{O}$ record. In: Berger, A., Imbrie, J., Hays, J.D., Kukla, G., Salzman, B. (Eds.), Milankovitch and Climate. Riedel, Norwell, MA, pp. 269-305.

King, J.W., Banerjee, S.K., Marvin, J.A., 1983. A new rock magnetic approach to selecting sediments for geomagnetic paleointensity studies: application to paleointensity for the last 4000 years. J. Geophys. Res. 88, 5911-5921.

Laskar, J., 1990. The chaotic motion of the solar system: a numerical estimate of the size of the chaotic zones. Icarus 88, 266-291.

Lean, C.M.B., McCave, I.N., 1998. Glacial to interglacial mineral magnetic and palaeoceanographic changes at Chatham Rise, SW Pacific Ocean. Earth Planet. Sci. Lett. 163, 247260.

Maher, B.A., 1988. Magnetic properties of some synthetic submicron magnetites. Geophys. J. 94, 83-96.

Maher, B.A., Hounslow, M.W., 1999. Palaeomonsoons II: magnetic records of aeolian dust in Quaternary sediments of the Indian Ocean. In: Maher, B.A., Thompson, R. (Eds.), Quaternary Climates, Environments and Magnetism. Cambridge Univ. Press, Cambridge, pp. 1-48.

Oldfield, F., 1994. Toward the discrimination of fine grained ferrimagnets by magnetic measurements in lake and nearshore marine sediments. J. Geophys. Res. 99, 9045-9050.
Paillard, D., Labeyrie, L., Yiou, P., 1996. Macintosh program performs time-series analysis. EOS Trans. AGU 77, 339.

Peck, J.A., King, J.W., Colman, S.M., Kravchinsky, V.A., 1994. A rock-magnetic record from Lake Baikal, Siberia: evidence for a late Quaternary climate change. Earth Planet. Sci. Lett. 122, 221-238.

Petit, J.R., Briatt, M., Royer, A., 1981. Ice age aerosol from East Antarctica ice core samples and past wind strength. Nature 293, 391-393.

Prell, W.L., Imbrie, J., Martinson, D.G., Morley, J.J., Pisias, N.G., Shackleton, N.J., Streeter, H.F., 1986. Graphic correlation of oxygen isotope stratigraphy: application to the late Quaternary. Paleoceanography 1, 137-162.

Reynolds, R.L., King, J.W., 1995. Magnetic records of climate change. Rev. Geophys. 33, 101-110.

Roberts, A.P., Cui, Y.L., Verosub, K.L., 1995. Wasp-waisted hysteresis loops: mineral magnetic characteristics and discrimination of components in mixed magnetic systems. J. Geophys. Res. 100, 17909-17924.

Robinson, S.G., 1986. The late Pleistocene paleoclimatic record of North Atlantic deep-sea sediments revealed by mineral-magnetic measurements. Phys. Earth Planet. Inter 42, $22-47$.

Rossignol-Strick, M., Nesteroff, W., Olive, P., Vergnaud-Grazzini, C., 1982. After the deluge; Mediterranean stagnation and sapropel formation. Nature 295, 105-110.

Shackleton, N.J., Berger, A., Peltier, W.R., 1990. An alternative astronomical calibration of the lower Pleistocene timescale based on ODP Site 677. Trans. R. Soc. Edin. Earth Sci. 81, 252-261.

Shackleton, N.J., Opdyke, N.D., 1973. Oxygen isotope and paleomagnetic stratigraphy of equatorial Pacific core V28238: oxygen isotope temperatures and ice volumes on a $10^{5}$ year and $10^{6}$ year scale. Quat. Res. 3, 39-55.

Stober, J.C., Thompson, R., 1979. Magnetic remanence acquisition in Finnish lake sediments. Geophys. J. R. Astron. Soc. 57, 727-739.

Tauxe, L., LaBrecque, J.L., Dodson, R., Fuller, M., 1983. U-channels - a new technique for paleomagnetic analysis of hydraulic piston cores. EOS Trans. AGU 64, 219.

Tauxe, L., Herbert, T., Shackleton, N.J., Kok, Y.S., 1996. Astronomical calibration of the Matuyama-Brunhes boundary: consequences for magnetic remanence acquisition in marine carbonates and the Asian loess sequences. Earth Planet. Sci. Lett. 140, 133-146.

Torii, M., 1997. Low-temperature oxidation and subsequent downcore dissolution of magnetite in deep-sea sediments, ODP Leg 161 (Western Mediterranean). J. Geomag. Geoelect. 49, 1233-1245.

Verosub, K.L., Roberts, A.P., 1995. Environmental magnetism: past, present, and future. J. Geophys. Res. 100, 2175-2192.

Williams, D.F., Thunell, R.C., Tappa, E., Rio, D., Raffi, I., 1988. Chronology of the Pleistocene oxygen isotope record: 0-1.88 m.y. B.P.. Palaeogeogr. Palaeoclimatol. Palaeoecol. 64, 221-240. 